\title{
Serogroups of Agrobacterium tumefaciens Biovar 3 Determined Using Somatic Antigens*
}

\author{
Hiroyuki SAWADA**, Jun IMADA** and Hiroyuki IEKI**
}

\begin{abstract}
Serological specificity of Agrobacterium tumefaciens biovar 3 was tested by means of agglutination and Ouchterlony double diffusion tests, using rabbit antisera prepared by injecting heat-treated $\left(100^{\circ} \mathrm{C}, 1 \mathrm{hr}\right)$ cell suspensions of 4 Japanese strains of G-Ag-19, 26,27 and 60 , and strain NCPPB 2562, a representative strain for biovar 3 isolated in Greece. In the agglutination test, 39 strains of biovar 3 except strain G-Ag-19 were separated into 4 distinct groups (A-D) according to the titers against 5 antisera. The same group-specific reactions were observed in the Ouchterlony double diffusion test as those in the agglutination test. Each of the biovar 3 strains except strain G-Ag-19 formed several group-specific precipitin bands only in combination with the antiserum prepared against the member of the same group. These results suggest that the biovar 3 strains used are serologically heterogeneous and can be separated into 4 serogroups (A-D), which differ from one another in the reactivity of somatic antigens (heat-stable antigens).
\end{abstract}

(Received May 23, 1991)

Key words: Agrobacterium tumefaciens, biovar 3, somatic antigen, serogroup, agglutination test, Ouchterlony double diffusion test.

\section{INTRODUCTION}

The incidence of grapevine crown gall disease has gradually increased in new plantations and nurseries in Japan ${ }^{12}$. It is postulated that the frequent occurrence of the disease results from planting of symptomlessly infected vines produced by vegetative propagation and wounding of them by freezing temperatures ${ }^{5}$. Thus, simple and convenient methods such as serodiagnosis for the detection of the causal agent, Agrobacterium tumefaciens biovar 3, are required to study the epidemiology and to index propagation materials.

Bishop et al. ${ }^{5)}$ produced a monoclonal antibody against biovar 3 and reported its application to diagnosis. However, Alarcon et al. ${ }^{1)}$ and Miller and Vruggink ${ }^{10)}$ reported the presence of serological heterogeneity within each of the Agrobacterium biovars and suggested the existence of several "serotypes". Moreover, Bouzar et al. ${ }^{2-4)}$ presented the evidence that lipopolysaccharide obtained from strain B6 (A.tumefaciens biovar 1) induced the production of strain-specific antibodies. Therefore, further studies are required to assess the serological specificity of biovar 3 , by using a larger number of strains derived from various sources.

In this paper, we examined the serological relationships among the biovar 3 strains, and classified them into serogroups according to the difference of somatic antigens.

\section{MATERIALS AND METHODS}

Bacteria. Serological relationships among the biovar 3 strains and specificity of antisera were

${ }^{*}$ Contribution No. E-144 of the Fruit Tree Research Station 果樹試験場業績番号：E-144

** Akitsu Branch, Fruit Tree Research Station, Ministry of Agriculture, Forestry and Fisheries, Akitsu, Hiroshima 729-24, Japan

農林水産省果樹試験場安芸津支場 
examined by using 65 strains of Agrobacterium, including 12 overseas strains, listed in Table 1 . In this paper, we follow the classical nomenclature of Agrobacterium presented in Bergey's Manual of Systematic Bacteriology ${ }^{8)}$ for the moment to avoid confusion, although another valid naming system was proposed $^{11)}$. Problems relating to the classification and nomenclature of Agrobacterium were discussed in the previous reports ${ }^{13,14}$. Three type strains of Rhizobium (Table 1), 12 species of phytopathogenic bacteria belonging to Clavibacter, Erwinia, Pseudomonas and Xanthomonas, and 2 strains of Escherichia coli were used for comparison.

Antisera. Strain NCPPB $2562^{8)}$, a representative strain for biovar 3 isolated in Greece, and four Japanese strains of G-Ag-19, 26, 27 and 60 identified as biovar $3^{12)}$ were used as antigens for the production of the antisera. Each strain was grown on a PPGA ${ }^{12)}$ slant for $48 \mathrm{hr}$ at $28^{\circ} \mathrm{C}$, suspended and washed in saline solution three times by centrifugation $(7,000 \mathrm{rpm}, 10 \mathrm{~min})$. The final precipitate was resuspended into saline solution at a concentration of $10^{\circ} \mathrm{cfu} / \mathrm{ml}$, and the suspension was heated at $100^{\circ} \mathrm{C}$ for $1 \mathrm{hr}$ to destroy heat-labile antigens. Somatic antigens (heat-treated cells) thus prepared were injected intramuscularly twice [mixed with an equal volume $(0.5 \mathrm{ml})$ of Freund's incomplete adjuvant] and intravenously 7 times ( $1 \mathrm{ml}$; twice, $1.5 \mathrm{ml}$; once, $2 \mathrm{ml} ; 4$ times) to rabbits. Blood was collected on the 7 th day after the final injection. Antiserum was heated at $56^{\circ} \mathrm{C}$ for $30 \mathrm{~min}$ to inactivate the complement and stored at $-80^{\circ} \mathrm{C}$.

Agglutination test. For testing the agglutination titer of antiserum, twofold dilutions of

Table 1. Strains of Agrobacterium and Rhizobium used in the present experiment

\begin{tabular}{|c|c|}
\hline Taxon & Strain ${ }^{a}$ \\
\hline \multicolumn{2}{|l|}{ Biovar 1} \\
\hline \multirow[t]{2}{*}{ A. tumefaciens } & NCPPB $2437^{* *}(\text { ATCC } 23308)^{\mathrm{b})}$ \\
\hline & MAFF 03-01001, 03-01222, 03-01224, 03-01278 \\
\hline A. rhizogenes & MAFF $03-01724,03-01725,03-01726,03-01727$ \\
\hline \multirow[t]{3}{*}{ A. radiobacter } & IAM $12048^{* *}$ (ATCC 19358, NCPPB 3001) \\
\hline & IAM 1527 (ATCC 6466) \\
\hline & IAM 1526 (ATCC 4718) \\
\hline \multicolumn{2}{|l|}{ Biovar 2} \\
\hline A. tumefaciens & NCPPB 2303*, MAFF 03-01546 \\
\hline A. rhizogenes & IFO $13257^{* *}$ (ATCC 11325, NCPPB 2991) \\
\hline A. radiobacter & Kerr $84^{*}$ (NCPPB 2407) \\
\hline \multicolumn{2}{|l|}{ Biovar 3} \\
\hline \multirow[t]{3}{*}{ A. tumefaciens } & NCPPB $2562^{*}$ \\
\hline & YGAt $32-3,33-1,35-2$ \\
\hline & $\begin{array}{l}\text { G-Ag- } 4,9,14,19,21,23,26,27,29,31,33,35,37,39,43,45,46 \\
\quad 48,50,52,54,56,57,58,59,60,61,62,63,64,65,66,67 \\
\text { K-Ag- } 1,2\end{array}$ \\
\hline
\end{tabular}

A. rubi

IFO $13261^{* *}$ (ATCC 13335, NCPPB 1854)

IFO 13260 (ATCC 13334, NCPPB 1856)

Unclassified

A. tumefaciens

NCPPB 1650, 1771

$\mathrm{K}-\mathrm{Ag}-3,4$

Ch-Ag- $4,5,7,8$

Rhizobium meliloti IAM 12611** (ATCC 9930, IFO 14782)

R. leguminosarum IAM 12609** (ATCC 10004, IFO 14778)

$R$. loti IAM 13588** (ATCC 33669, IFO 14779)

a) For assignment of strains to taxa and their origin, see previous reports ${ }^{12,13)}$.

${ }^{*}$ : representative strain for the corresponding $\operatorname{biovar}^{8)} .^{* *}$ : type strain.

b) The numbers in parentheses are other strain designations.

Abbreviations for culture collections : ATCC, American Type

Culture Collection; IAM, Institute of Applied Microbiology,

University of Tokyo; IFO, Institute for Fermentation;

MAFF, Ministry of Agriculture, Forestry and Fisheries, Japan;

NCPPB, National Collection of Plant Pathogenic Bacteria. 
antiserum were prepared from 1:20 to 1:40, 960 with $0.5 \mathrm{ml}$ of saline for dilution in tubes. To each of the above tubes, an equal volume of antigen (living cell suspension at a concentration of $10^{9} \mathrm{cfu} / \mathrm{ml}$ ) was added. The tubes were incubated at $37^{\circ} \mathrm{C}$ for $2 \mathrm{hr}$ and then kept at $4^{\circ} \mathrm{C}$ overnight, until agglutination was observed. The agglutination titer was expressed as the reciprocal of the highest dilution in which distinct agglutination occurred.

Ouchterlony double diffusion test. Sixteen $\mathrm{ml}$ of agar gel [Tris- $\mathrm{HCl}$ buffer (0.2 M, pH 7.4) 100 $\mathrm{ml}$, polyethylene glycol $3 \mathrm{~g}, \mathrm{NaN}_{3} 0.1 \mathrm{~g}$, agar $1.5 \mathrm{~g}$ ] was dispensed into a 9-cm petri dish. Wells, $4 \mathrm{~mm}$ in diameter and $4 \mathrm{~mm}$ apart, were cut in sets of six peripheral wells surrounding a center well. Twenty $\mu 1$ of undiluted antisera and antigens (heat-treated dense suspensions) were dispensed into the wells, and the plates were incubated at $28^{\circ} \mathrm{C}$ and obserwed for 1 week.

\section{RESULTS}

\section{Specificity of antisera}

Five antisera prepared against strains G-Ag-27, 26, 60, NCPPB 2562 and G-Ag-19 gave high agglutination titers of 2,562,20,480,10,240,2,562 and 2,562, respectively, in homologous combinations (Table 2). In contrast, these antisera gave no visible agglutination against strains other than biovar 3 , except that strain K84 (A. radiobacter biovar 2), R. meliloti, R. loti, P. solanacearum and E. coli showed extremely low titers ranging from 20 to 160 against some of these antisera (data not shown). Moreover, these antisera formed no precipitin bands in combination with strains other than biovar 3 (data not shown). Thus, all the antisera produced in the present experiment were found to be highly specific.

\section{Agglutination test}

To clarify the serological relationships among the biovar 3 strains, 40 strains of biovar 3 isolated from grapevine and kiwifruit were examined by cross-agglutination test. Thirty-nine strains except strain $\mathrm{G}-\mathrm{Ag}-19$ were divided into 4 distinct groups (A-D) according to the titers against 5 antisera (Table 2). Namely, 29 strains of group A, including strain G-Ag-27, showed high titers only in combination with the antiserum prepared against strain G-Ag-27, whereas they gave low titers against the others. Two kiwifruit isolates (K-Ag-1 and 2) also belonged to group A. Eight strains, which reacted strongly only with the antiserum prepared against strain G-Ag-26, were assigned to group B. The antisera prepared against strains G-Ag-60 and NCPPB 2562 were specific to only homologous strains, indicating that these two strains are serologically distinct and can be separated into groups $C$ and $D$, respectively. Although strain G-Ag-19 exhibited strong reactions to all the 5 antisera, the antiserum prepared against

Table 2. Agglutination titers of antisera to heat-treated cells of biovar 3 against biovar 3 strains

\begin{tabular}{|c|c|c|c|c|c|c|}
\hline \multirow{2}{*}{ Serogroup } & \multirow{2}{*}{ Strain } & \multicolumn{5}{|c|}{ Antiserum to heat-treated cells of } \\
\hline & & G-Ag-27 & $\mathrm{G}-\mathrm{Ag}-26$ & G-Ag-60 & NCPPB 2562 & G-Ag-19 \\
\hline $\mathrm{A}$ & $\begin{array}{l}\text { G-Ag- } 4,9,14,27,29,31 \\
\quad 33,35,37,39,43,45 \\
50,52,54,56,57,58 \\
\quad 59,62,63,64,65 \\
\text { YGAt } 32-3,33-1,35-2 \\
\text { K-Ag- } 1,2 \\
\text { NCPPB } 1771\end{array}$ & $\begin{array}{c}640 \\
5 \\
5,120 \\
(2,560)^{\text {a) }}\end{array}$ & $\int_{640}^{160}$ & $\underset{640}{40}$ & $\int_{160}^{20}$ & $\begin{array}{c}40 \\
3 \\
80\end{array}$ \\
\hline B & $\begin{array}{l}\text { G-Ag- } 21,23,26,46,48 \\
\quad 61,66,67\end{array}$ & $\int_{80}^{20}$ & $\begin{array}{c}5,120 \\
\int_{20,480} \\
(20,480)^{a)}\end{array}$ & $\int_{320}^{40}$ & $\underset{160}{20}$ & $\stackrel{80}{\delta}$ \\
\hline $\mathrm{C}$ & G-Ag-60 & 40 & 160 & 10,240 & 160 & 80 \\
\hline $\mathrm{D}$ & NCPPB 2562 & 80 & 80 & 40 & 2,560 & 20 \\
\hline (not grouped) & G-Ag-19 & 5,120 & 10,240 & 5,120 & 2,560 & 2,560 \\
\hline
\end{tabular}

a) Titer obtained in homologous combination. 
Table 3. Ouchterlony double diffusion reaction of antisera to heat-treated cells of biovar 3 against biovar 3 strains

\begin{tabular}{|c|c|c|c|c|c|c|c|}
\hline \multirow{2}{*}{ Serogroup ${ }^{a)}$} & \multirow{2}{*}{$\begin{array}{l}\text { Number } \\
\text { of } \\
\text { strains }^{\text {a) }}\end{array}$} & \multirow{2}{*}{$\begin{array}{l}\text { Common } \\
\text { precipitin } \\
\text { band }^{\text {b) }}\end{array}$} & \multicolumn{5}{|c|}{ Antiserum to heat-treated cells of } \\
\hline & & & G-Ag-27 & $\mathrm{G}-\mathrm{Ag}-26$ & G-Ag-60 & NCPPB 2562 & G-Ag-19 \\
\hline A & 29 & $+c)$ & $>3^{\mathrm{d})}$ & 0 & 0 & 0 & 0 \\
\hline $\mathrm{B}$ & 8 & + & 0 & $>1$ & 0 & 0 & 0 \\
\hline $\mathrm{C}$ & 1 & + & 0 & 0 & $>2$ & 0 & 0 \\
\hline $\mathrm{D}$ & 1 & + & 0 & 0 & 0 & $>2$ & 0 \\
\hline (G-Ag-19) & 1 & + & 0 & 0 & 0 & 0 & 0 \\
\hline
\end{tabular}

a) See Table 2 .

b) See Fig. 1 .

c) + : common bands which coalesced and fused completely with each other were produced against antisera to biovar 3 .

d) Number of serogroup-specific bands formed against each antiserum.

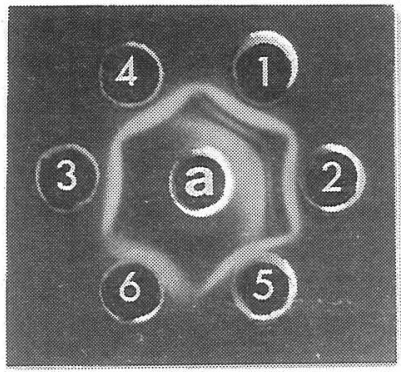

I

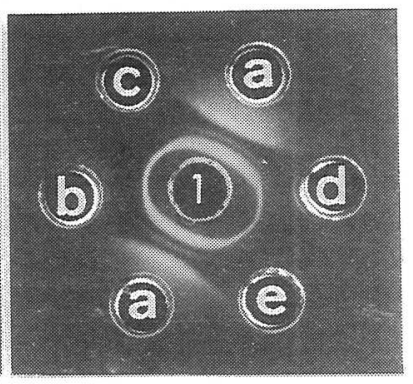

II

Fig. 1. Ouchterlony double diffusion patterns of antisera to heat-treated cells of biovar 3 against representative strains of serogroups. Wells a, b, c, d and e contained antiserum to G-Ag-27 (serogroup A), G-Ag-26 (B), G-Ag-60 (C), NCPPB 2562 (D) and G-Ag-19 (ungrouped), respectively. Wells 1, 2, 3, 4, 5 and 6 contained heat-treated cells of G-Ag-27 (A), NCPPB 1771 (A), G-Ag-26 (B), G-Ag-60 (C), NCPPB 2562 (D) and G-Ag-19 (ungrouped), respectively. A single, common precipitin band which coalesced and fused completely with the others was produced (outermost; panel I, innermost; panel II). Serogroup A-specific bands were observed (near the center well; panel I, near the well a; panel II).

strain G-Ag-19 was found to be strain-specific, which indicated that strain G-Ag-19 is serologically unique.

\section{Ouchterlony double diffusion test}

The same group-specific reactions as those in the agglutination test were observed in the Ouchterlony double diffusion test (Table 3 and Fig. 1). Each of the 39 strains except strain G-Ag-19 formed several group-specific precipitin bands only in combination with the antiserum prepared against the member of the same group. On the other hand, a single, common precipitin band was produced in all the combinations, which coalesced and fused completely with the others (Fig. 1).

\section{DISCUSSION}

Alarcon et al. ${ }^{1)}$ and Miller and Vruggink ${ }^{10)}$ suggested the existence of several "serotypes" within each of biovars 1, 2 and 3, because they observed serological heterogeneity in each of them. The variability in the reactions of the biovar 3 strains obtained in the agglutination and Ouchterlony double diffusion tests in the present experiment (Tables 2, 3 and Fig. 1) supports their results. Moreover, the data obtained in both methods were found to corroborate each other, and the biovar 3 strains tested could be separated into 4 distinct groups, which differed from one another in the reactivity of somatic antigens (heat-stable antigens). We concluded that these groups should be considered as "serogroups" 
rather than "serovars", because the antigens which were used to produce the antisera were limited to unrefined somatic ones.

The use of the serogroup-specific antisera prepared in the present experiment and the development of a suitable serological technique may enable the rapid differentiation among biovar 3 serogroups, which will be useful to study the epidemiological characteristics and to index propagation materials. However, further studies are needed to develop a practical serodiagnosis for this purpose by estimating the suitability and convenience of various serological techniques.

Keane et $a{ }^{6}{ }^{6}$ and Lopez ${ }^{9}$ produced specific antisera which enabled to distinguish biovars 1 and 2 serologically. As for biovar 3, Bishop et al..$^{5)}$ and Ophel and $\mathrm{Kerr}^{11)}$ reported the existence of serological specificity, by using a monoclonal antibody prepared against biovar 3 . In the present experiment as well, the presence of a somatic antigen in common with all the biovar 3 strains was detected, because a single, common precipitin band which coalesced and fused completely with the others was produced in only the biovar 3 strains. This antigen may be associated with the serological specificity of biovar 3 observed by Bishop et al..$^{5)}$ and Ophel and Kerr ${ }^{11)}$.

Strain NCPPB 1771, treated as an aberrant strain hitherto ${ }^{7,8)}$, showed the same serological reactions as serogroup A of biovar 3 (Table 2 and Fig. 1). We concluded that it should be assigned to biovar 3, because it was also similar to biovar 3 in terms of phenotypic characteristics and fatty acid methyl ester profiles in our experiments ${ }^{13,14)}$. Strain G-Ag-19, which was found to be serologically unique (Tables 2 and 3), remains to be grouped. Detailed antigen analysis is required to clarify its position.

We wish to thank Dr. K. Tsuchiya, National Institute of Agrobiological Resources, for his kind suggestions.

\section{Literature cited}

1. Alarcon, B., Lopez, M.M., Cambra, M. and Ortiz, J. (1987). Comparative study of Agrobacterium biotypes 1,2 and 3 by electrophoresis and serological methods. J. appl. Bact. $62: 295-308$.

2. Bouzar, H., Moore, L.W. and Schaup, H.W. (1986). Importance of ribosome purity in ribosomal serology. Phytopathology 76 : 1323-1325.

3. Bouzar, H. and Moore, L.W. (1987). Complementary methodologies to identify specific Agrobacterium strains. Appl. Environ. Microbiol. 53 : 2660-2665.

4. Bouzar, H., Moore, L.W. and Schaup, H.W. (1988). Lipopolysaccharide from Agrobacterium tumefaciens B6 induces the production of strain-specific antibodies. Phytopathology $78: 1237-1241$.

5. Bishop, A.L., Burr, T.J., Mittak, V.L. and Katz, B.H. (1989). A monoclonal antibody specific to Agrobacterium tumefaciens biovar 3 and its utilization for indexing grapevine propagation material. Phytopathology 79: 995-998.

6. Keane, P.J., Kerr, A. and New, P.B. (1970). Crown gall of stone fruit II. Identification and nomenclature of Agrobacterium isolates. Aust. J. biol. Sci. $23: 585-595$.

7. Kersters, K., DeLey, J., Sneath, P.H.A. and Sackin, M. (1973). Numerical taxonomic analysis of Agrobacterium. J. Gen. Microbiol. 78 : 227-239.

8. Kersters, K. and DeLey, J. (1984). Agrobacterium Conn 1942. In Bergey's Manual of Systematic Bacteriology (Krieg, N.R. and Holt, J.G. eds.). Vol. 1. Williams and Wilkins, Baltimore. pp. 244-254.

9. Lopez, M. (1978). Characteristics of French isolates of Agrobacterium. In Proc. 4th Int. Conf. Plant Path. Bact., Angers. pp. 233-237.

10. Miller, H.J. and Vruggink, H. (1981). An assessment of biochemical and serological tests for Agrobacterium radiobacter subsp. tumefaciens. Phytopath. Z. $102: 292-300$.

11. Ophel, K. and Kerr, A. (1990). Agrobacterium vitis sp. nov. for strains of Agrobacterium biovar 3 from grapevines. Int. J. Syst. Bacteriol. 40 : 236-241.

12. Sawada, H., Ieki, H. and Takikawa, Y. (1990). Identification of grapevine crown gall bacteria isolated in Japan. Ann. Phytopath. Soc. Japan 56 : 199-206.

13. Sawada, H. and Ieki, H. (1992). Phenotypic characteristics of the genus Agrobacterium. Ann. Phytopath. Soc. Japan $58: 37-45$.

14. Sawada, H., Takikawa, Y. and Ieki, H. (1992). Fatty acid methyl ester profiles of the genus Agrobacterium. Ann. Phytopath. Soc. Japan 58: 46-51. 


\section{和 文 摘 要}

澤田宏之・今田＼cjkstart準・家城洋之：Agrobacterium tumefaciens biovar 3 の菌体抗原に基づく血清群分化

Agrobacterium tumefaciens biovar 3 の血清学的性質を調べるため，ブドウから分離した 5 菌株の biovar 3 (G-Ag19, 26, 27, 60 および NCPPB 2562）を $100^{\circ} \mathrm{C} て ゙ 1$ 時間加熱処理し，得られた菌体抗原を免疫原として家兔を用いて抗 血清を作製した。40 菌株(外国産の 12 菌株を含む)の biovar 3 を抗原として試験管内凝集反応を行ったところ, G-Ag19 を除いた 39 菌株は, 作製した 5 種の抗血清に対する凝集素価に従って $\mathrm{A} \sim \mathrm{D}$ の四つのグループに分かれた。寒天ゲ ル内二重拡散法でも同様に四つのグループ間で反応に差が認められた。すなわち, 全菌株に共通な 1 本の沈降帯のほか に, 各グループごとに特異的な沈降帯が数本形成された。以上のことから, 供試した 39 菌株の biovar 3 は, 菌体抗原 の相違に基づく四つの血清群（serogroup）に類別できることが明らかとなった。 